Makale Gelis | Received: 27.06.2020.

Makale Kabul | Accepted: 19.07.2020.

DOI: ??

Mavi Atlas, 8(2)2020: 196-209

Araştırma Makalesi|Research Article

Burcu YILDIRAY
Ondokuz Mays Üniversitesi, Eğitim Bilimleri Enstitüsü, Eğitim Bilimleri Bölümü, Samsun-TÜRKIYE
Yüksek Lisans Örencisiaduate Student
Ondokuz Mayıs University, Institute of Educational Science, Department of Educational Science, Samsun-TURKEY
ORCID: 0000-0002-6550-4598
burcu.yildiray28@gmail.com

Seher BALCI ÇELİK

Prof. Dr.|Prof. Dr.

Ondokuz Mayıs Üniversitesi, Eğitim Fakültesi, Eğitim Bilimleri Bölümü, Samsun-TÜRKIYYE

Ondokuz Mayis University, Faculty of Education, Department of Educational Science, Samsun-TURKEY

ORCID: 0000-0001-9506-6528

sbalci@omu.edu.tr

\title{
Üniversite Öğrencilerinin Toplumsal Cinsiyet Rolleri ile Evlilik Dışı Cinsel Yakınlığa Yönelik Tutumlar1 ${ }^{1}$
}

Öz

Bu araştırmanın amacı, üniversite öğrencilerinin toplumsal cinsiyet rolleri ile evlilik dışı cinsel yakınlığa yönelik tutumları arasındaki ilişkiyi çeşitli değişkenler açısından incelemektir. Araştırmanın çalışma grubunu, Orta Karadeniz'de bir devlet üniversitesinde öğrenim görmekte olan ve tabakalı örnekleme yöntemi ile ulaşılan 247'si kadın 174'ü erkek olmak üzere toplamda 421 üniversite öğrencisi oluşturmaktadır. Bu çalışma grubuna toplumsal cinsiyet rolleri tutum ölçeği ve evlilik dışı cinsel yakınlığa yönelik tutum ölçeği uygulanmıştır. Bu çalışmada ilişkisel tarama modeli kullanılmıştır. Toplumsal cinsiyet rolleri ve evlilik dışı cinsel yakınlığa yönelik tutum arasında ilişkinin olup olmadığını tespit etmek için Pearson korelasyon analizi yapılmıştır. Toplumsal cinsiyet rolleri ve evlilik dışı cinsel yakınlığa yönelik tutum arasındaki ilişkinin cinsiyete göre farklılaşıp farklılaşmadığını tespit etmek amacıyla Bağımsız Örneklem t-Testi, diğer değişkenlere göre farklılaşıp farklılaşmadığını test etmek için Tek Yönlü Manova Analizi uygulanmıştır. Farklılaşmanın hangi gruplardan kaynaklandığını tespit etmek amacıyla Tukey Testi uygulanmıştır. Sonuç olarak üniversite öğrencilerinin toplumsal cinsiyet rolleri ile evlilik dışı cinsel yakınlığa yönelik tutumları arasında anlamlı bir ilişki bulunmuştur. Bunun yanı sıra toplumsal cinsiyet rolleri ile evlilik dışı cinsel yakınlığa yönelik tutum arasındaki ilişkinin cinsiyete, öğrenim görülen fakülte türüne ve bireyin yaşamının büyük bir bölümünü geçirdiği yere göre anlamlı bir farklılık gösterirken bireyin sosyo-ekonomik durumuna göre anlamlı bir farklılık göstermediği saptanmıştır. Elde edilen bulgular literatür 1şığında tartışılmıştır ve bu alanda çalışanlara önerilerde bulunulmuştur.

Anahtar Kelimeler: Toplumsal Cinsiyet Rolleri, Evlilik Dışı Cinsel Yakınlığa Yönelik Tutum, Üniversite Öğrencileri.

\section{University Students' Gender Roles and Their Attitudes Towards Out-of-Marriage Sexual Intimacy}

\begin{abstract}
The aim of this study is to examine the relation between the gender roles of university students and their attitudes toward out-of-marriage sexual intimacy in terms of several variables. The study group of the research constitutes 421 university students in total, including 247 women and 174 men that study a state university in Central Black Sea and reached by stratified sampling method. Gender role attitude scale and out-of-marriage sexual intimacy attitude scale were applied to this study group. In this study, correlational survey model was used. Pearson's correlation analysis was conducted to determine whether there is a relationship between gender roles and attitude towards out-of-marriage sexual intimacy. To determine the correlation between gender roles and out-of-marriage sexual intimacy differs according to gender, Independent Samples t-Test; to test whether it differentiates according to other variables. OneWay Manova Analysis was performed. Tukey Test way applied to assess which group is the source of deviation. As a
\end{abstract}

\footnotetext{
${ }^{1}$ Bu çalışma için Ondokuz Mayıs Üniversitesi Sosyal ve Beşeri Bilimler Etik Kurulu’ndan gerekli izinler alınmıştır
} (17.04.2020 tarihli ve 2020/160 no'lu karar). 
result, a significant correlation was found between the gender roles of university students and their attitudes towards out-of-marriage sexual intimacy. In addition, while the correlation between gender roles and attitude towards out-ofmarriage sexual intimacy differs significantly according to gender, the type of faculty studied and the place where the individual spends most of his/her life, there was no significant difference determined according to individual's socioeconomic status. The findings were discussed in consideration of the literature and suggestions were given to people working in the field.

Keywords: Gender Roles, Toward Out-Of-Marriage Sexual Intimacy, College Students.

\section{Giriş}

Kadın ve erkek arasındaki farklılıklar, insanlığın bașından beri karșımıza çıkmakta olan bir olgudur. Tarihe bakıldığında kadınların erkeklerden net bir sınırla ayrıldığı, ikincil bir konuma alındığı görülmektedir. Örneğin kiliselerde kadının ruhunun olup olmadığı hatta kadınların birer insan olup olmadığ1 bile tartışılan konulardan biri olmuştur (Adler, 2019: 12). Görülen bu farklılıkların açılanması için ortaya atılan cinsiyet ve toplumsal cinsiyet kavramlarına bakıldığında Türkiye' de toplumsal cinsiyeti açıklamak için de cinsiyet kavramı kullanıldığı, farklı dillerde ise cinsiyet ve toplumsal cinsiyetin daha net sınırlarla ayrıldığı görülmektedir. Örneğin İngilizcede cinsiyet kavramı "sex" ile, toplumsal cinsiyet kavramı ise "gender" şeklinde ifade edilmiştir (Ertürk, 2017: 379). Ayrı ayrı incelendiğinde cinsiyet kavramının bir bireyin kadın ya da erkek olduğunu gösteren genetik, fizyolojik veya biyolojik özellikler olduğu görülürken (Gender and Health: Technical Paper, 1998: 10) toplumsal cinsiyet kavramına bakıldığı zaman ise bu kavramın kadının ve erkeğin toplumsal ve kültürel açıdan açıklanması, bu iki tarafın birbirinden ayırt edilmesi ve ayrı ayrı bireylere atfedilen rolleri betimlemek amacıyla kullanılan bir kavram olduğu görülmektedir (Ecevit, 2011: 4). İnsanların sahip olduğu bu toplumsal cinsiyete ilişkin roller hayatın pek çok alanını etkilemekte, kadın veya erkek olmaktan doğan farklılıklar yaşanılan hayatın her anında bireylerin karşısına çıkabilmektedir. Örneğin, aynı iş yerinde çalışan bir kadın ve bir erkeğin önüne farklı cinsiyete sahip olduklarından dolayı farklı engeller çıkabilmektedir. (Akın ve Demirel, 2003: 73). Insanlar, toplumsal cinsiyet rollerinin etkisine doğdukları andan itibaren girmeye başlar ve bu cinsiyet rollerinin etkisine daha küçük yaşta girmeye başlayan çocuk ister istemez davranışlarını bu yönde sergilemeye başlar. Örneğin cinsiyet ayrımını gösteren deyimleri ve atasözlerini ailesinde ve çevresinde sürekli duyan çocuk bir süreden sonra davranışlarını bu yönde șekillendirebilir veya çocukların arkadaşları ile geçirdikleri vakitlerde oynadıkları oyuncaklar ve oyunlar da cinsiyete yönelik kalıp yargılara ilişkin ipuçları verir (Sabuncuoğlu, 2006: 115-116). Bunun yanında çocukların küçüklükten itibaren giydikleri kıyafetlerin seçimlerinde bile toplumsal cinsiyet rollerine ilişkin ipuçları görülmektedir. Örneğin kız çocuklarının elbiselerle erkek çocuklarının ise küçüklükten beri ceket ve kravat gibi kıyafetlerle büyütülmesi onlara cinsiyet rollerini aşılamaktadır (Tarhan, 2010: 101-108).

Kadının ve erkeğin farklılaştı̆ğ alanlardan biri ise cinselliktir. Örneğin Freud (2017: 75) küçük kız çocuklarının erkeklere kıyasla cinsel baskılanmayı daha çok yaşadıklarını ya da utanç ve nefret gibi cinsel engellemelerin de kız çocuklarda erkek çocuklardan daha erken ortaya çıktığını belirtmiștir (Freud, 2017: 75). Cinsellik kavramına bakıldığında bu kavramın, bireylerin diğer cinse karşı oluşan ilgisi sonucunda meydana gelen duyguları ve fiziksel davranışların tümünü ifade ettiği görülmektedir (Taşç1, 2017: 12). Cinsellik kavramı cinsiyet, toplumsal cinsiyet, cinsel yönelim, memnuniyet, yakınlık ve üreme gibi kavramları içinde barındıran ve biyolojik, psikolojik, kültürel, sosyal, ekonomik, politik, dini ve tarihsel gibi pek çok faktörün birleşiminden etkilenen bir kavramdır (Defining Sexual Health, 2002: 5). Cinsellikte farklı bakış açıları bulunmaktadır. Bu bakış açıları "biyolojik", "psikolojik" ve "sosyokültürel” bakış açısı olarak sınıflandırılabilir (Cinsel Yaşam ve Sorunları, 2007: 15). "Biyolojik”" bakıș açısına göre cinsellik bireylerin ana içgüdülerinden biridir ve sağlıklı bir cinsel yaşam için sağlıklı bir bedene sahip olunması gerekmektedir. "Psikolojik" bakış açısına göre bireylerin kişilik özellikleri, geçmişteki yaşadıkları ve sahip oldukları travmaları gibi unsurlar cinselliği etkilemektedir. Son olarak "sosyokültürel" bakış açısına göre bireyin bulunduğu 
aile, yaşamını geçirdiği toplum ve sahip olduğu dini inanç, gelenek görenek gibi etkenler bireylerin cinsel yaşamında etkilidir. Cinsellik hakkında "ergenlik döneminde çıkan ve yaşl1lık döneminde sönen bir olgudur" görüşü yerini "bireyin doğumundan ölümüne kadar onunla olan ve onu haz elde etmeye yönelten bir dürtü” görüşüne bırakmıştır (Bakırcıoğlu, 2011: 288). Cinsellik, esas işlevi olan üreme etkinliğine birey ergenlik dönemine girince sahip olur. Karşı cinse duyulmaya başlayan ilgi ergenliğin son yıllarında açıkça ortaya çıkar. Kızlar bu dönemde erkeklere karşı ilgilerini daha çok gizli yaşamaktayken erkekler ise kızlarla ilgilendiklerini açık açık belli etmektedir. (Bakırcıoğlu, 2011: 281-286) Bireylerin cinsel gereksinimlerini engeller ve yasaklar olmadan giderebileceği bir kurum olarak ifade edilen evlilik, insanların cinselliklerini yaşamaları için tercih ettikleri bir seçenektir (Bakırcıoğlu, 2011: 171). Çünkü insanların büyüdüğü toplumun cinselliğe olan bakış açısı bireyin kendi bakış açısını da etkilemektedir ve bu değişik bakış açılarının birbirinden ayrılan noktalarından biri evlilik olmadan yapılan cinselliğe olan bakış açısıdır. Örneğin bazı toplumların bakış açısına göre bireyler evlilik dışında cinsel ilişkiye kesinlikle girmemelidir. Bunların yanı sıra evlilik dışı cinsel ilişkiyi hoş karşılamayan fakat tepki de göstermeyen toplumlar da bulunmaktadır (Yeşiltepe Oskay, 2005: 261). Cinsel ilişki, bireylerin cinselliği ile ilgili olan davranışlarından yalnızca biridir. Cinsel davranış, cinsel ilişkiyi de içine alan geniş bir kavramdır. Cinsel davranış kavramının içindeki başka bir kavram olan cinsel yakınlık ise cinsel birleşmenin olmadığı, öpüşme, birbirini okşama, birbirlerine erotik şakalar yapma veya erotik öyküler okuma ya da sadece bakışma gibi davranışlar olarak tanımlanmaktadır (Bozdemir ve Özcan, 2011: 39). Cinsel yakınlık ergenlik döneminde görülmeye başlanır. Birey ergenlik döneminde ilgi göstermeye başladığ1 kişiye hem duygusal hem de fiziksel olarak yakınlık göstermeyi ister. Yapılan bazı davranışlar, normalde cinsel bir davranış olmamakla beraber karşı tarafa hissettirdikleri ile birlikte cinsel yakınlığa ilisskin davranışlara örnek olarak verilebilir. Örneğin karşılıklı konuşma bile ses ve ton bakımından kişiyi cinselliğe çekebilir veya kolu karşı tarafin beline dolama davranışı eğer flört ilişkisi kuran iki kişi arasında gerçekleşiyorsa cinsel yakınlı̆̆a uygun bir davranış olur. Çünkü kişinin kolunu karşı cinsin beline dolaması cinselliği açıkça ortaya koyan bir davranış olarak nitelendirilmektedir (Hayta ve Algin, 2013: 59-74).

$\mathrm{Bu}$ araştırma, toplumsal cinsiyet rollerinin evlilik dışı cinsel yakınlı̆̆a yönelik tutumlarla herhangi bir ilişkinin olup olmadığı incelemek amacıyla yapılmıştır. İlgili literatür incelendiğinde toplumsal cinsiyet rolleri ile cinsel davranışlar, cinsel mitler veya cinsel tabular arasındaki ilişkiyi inceleyen araştırmalar görülmekte fakat evlilik dışı cinsel yakınlıkla ilgili herhangi bir çalışma görülmemektedir. Bu çalışma ile cinsel davranışlardan biri olan cinsel yakınlık ile ilgili farkındalık oluşturulması ve ilgili alana katkı sağlaması; ayrıca toplumsal cinsiyet rollerinin insanların cinsel yakınlıklarıyla olan ilişkisini belirleyerek ilgili alanyazına katkı sağlanması hedeflenmektedir.

\section{Yöntem}

\section{Evren ve Örneklem}

$\mathrm{Bu}$ araştırma nicel bir araştırma olup ilişkisel tarama modeli ile yürütülmüştür. Araştırmanın evrenini Ondokuz Mayıs Üniversitesi'nde öğrenim görmekte olan öğrenciler oluşturmaktadır. Bu evrenden örneklem seçimi planlanmış ve tabakalı örnekleme yöntemiyle örneklem seçimine gidilmiştir. Ondokuz Mayıs Üniversitesi’nde bulunan 19 tane fakülte, tabakalar olarak sayılmış ve ayr1 ayrı her fakültede bulunan öğrencilerin sayısı tüm evren sayısına bölünerek tabaka ağırlı̆̆1 hesaplanmıştır. Bulunan tabaka ağırlı̆̆ sayıları ise ulaşılmak istenen örneklem sayısı ile çarpılarak her fakülteden veri toplanacak öğrenci sayısı yaklaşık olarak 500 kişi olarak hesaplanmışır. $\mathrm{Bu}$ kapsamda Ondokuz Mayıs Üniversitesi Sosyal ve Beşeri Bilimler Etik Kurulu'ndan gerekli onay alınmış (17.04.2020 tarihli ve 2020/160 no'lu karar) ve elde edilen verilerle yapılan analizler sonucunda kişi sayısı 20'den düşük olan fakülteler araştırmadan çıkarılmıştır.

Araştırmaya katılan öğrencilerin \%58,7'si kadın, \%41,3’ü ise erkektir. Bu öğrencilerin \%19,2'si Eğitim Fakültesi, \%14,5’i Fen Edebiyat Fakültesi, \%15,2'si Mühendislik Fakültesi, 
\%15,4’ü İlahiyat Fakültesi, \%5,9’u Ziraat Fakültesi, \%7,1’i Sağlık Bilimleri Fakültesi, \%8,3’ü Tip Fakültesi, \%6,2'si Spor Bilimleri Fakültesi ve \%8,1’i ise İktisadi ve İdari Bilimler Fakültesi'nde öğrenim görmektedir. Örneklemde yer alan kişilerin \%12,8’i köyde, \%25,9’u ilçede ve \%61,3’ü ise şehirde yaşamaktadır. Bu bireylerin \%28,7'si düşük sosyoekonomik düzeye \%53,2'si orta ekonomik düzeye ve son olarak $\% 18$ ' 1 ’ ise yüksek sosyoekonomik düzeye sahiptirler.

\section{Veri Toplama Araçları}

Kişisel Bilgi Formu: Kişisel bilgi formunda araştırmanın amacı kapsamında bağımsız değişkenler olan cinsiyet, öğrenim görülen fakülte, bireyin sosyo-ekonomik durumu, bireyin yaşamının büyük bir bölümünü geçirdiği yer, bireyin annesinin ve babasının eğitim durumu yer almıștır.

Toplumsal Cinsiyet Rolleri Tutum Ölçeği (TCRTÖ): Zeyneloğlu ve Terzioğlu (2011) tarafindan geliştirilen Toplumsal Cinsiyet Rolleri Ölçeği tabakalı rastgele örnekleme yöntemi kullanılarak 500 öğrenci üzerinde geliştirilmiştir. 38 maddeden oluşan ölçek 'kadın cinsiyet rolü, erkek cinsiyet rolü, evlilikte cinsiyet rolü, eşitlikçi cinsiyet rolü ve geleneksel cinsiyet rolü’ olmak üzere 5 alt boyuttan oluşmaktadır. Bu çalışmada alt boyuttaki özellikler ayrı ayrı değerlendirilmemiş, ölçekten alınan toplam puanlar üzerinden değerlendirme yapılmıştır. Ölçeğin iç tutarlılık katsayısı 0.92 olarak hesaplanmıștır. Bu çalışmada ise ölçeğin iç tutarlık katsayısı 0.94 olarak hesaplanmıștır. Ölçek 5’li likert tipi bir ölçek olup ölçekten alınabilecek en yüksek toplam puan 190 iken alınabilecek en düşük puan 38'dir. Ölçekten alınan yüksek puanlar bireyin eşitlikçi bir tutuma sahip olduğunu gösterirken alınan düşük puan ise bireyin gelenekçi bir tutuma sahip olduğunu göstermektedir.

Evlilik Dışı Cinsel Yakınlı̆ga Yönelik Tutum Ölçeği (EDCYYTÖ): Y1ldıray ve arkadaşları (2019) tarafından geliştirilen Evlilik Dışı Cinsel Yakınlığa Yönelik Tutum Ölçeği, 350 kişi üzerinde geliştirilmiştir. Ölçekte 26 madde bulunmakta olup tek boyutlu bir ölçektir. Ölçek 5'li likert tipi bir ölçek olup, bu ölçekten alınabilecek en düşük puan 26, alınabilecek en yüksek puan 130'dur. Ölçeğin güvenirliğini test etmek amacıyla yapılan iç tutarlılık katsayısı 0.94 iken iki yarı güvenirlik katsayısı 0.85 olarak hesaplanmıştır. Bu çalışmada ise ölçeğin iç tutarlık katsayısı 0.94, iki yarı güvenirliği katsayısı 0.79 olarak hesaplanmıştır. Ölçeğin geçerliliği için yapılan AFA sonucunda ölçeğin tek boyutlu olduğu görülmekte ve toplam varyansın \%69,12'sini açıklamaktadır. Ölçekten alınan yüksek puanlar bireyin evlilik dışı cinsel yakınlığa yönelik olumlu bir tutuma sahip olduğunu gösterirken alınan düşük puanlar ise bireylerin olumsuz bir tutuma sahip olduklarını göstermektedir.

\section{İşlem}

Araştırmanın bağımsız değişkenleri cinsiyet, sosyo-ekonomik düzey, yaşamının büyük bölümünü geçirdiği yer, fakülte ve anne-baba eğitim düzeyidir. Bağımlı değișkenler ise Toplumsal Cinsiyet Rolleri Tutum Ölçeği ve Evlilik Dıșı Cinsel Yakınlığa Yönelik Tutum Ölçeği’ nden alınan puanlardır. Katılımcıların verilen ölçekleri doldurma süreleri 15 ile 20 dakika arasındadır. $\mathrm{Bu}$ araştırma kapsamında kullanılan ölçme araçları, Ondokuz Mayıs Üniversitesi'nde lisans eğitimi görmekte olan 421 öğrenciye internet üzerinden ulaşılarak uygulanmıştır.

\section{Verilerin Analizi}

Araştırmada veri toplama araçlarından elde edilen veriler SPSS 20 paket programı kullanılarak analiz edilmiştir. Öncelikle iki bağımlı değişken arasındaki ilişki olup olmadığı Pearson Korelasyon Katsayısı ile test edilmiştir. Toplumsal cinsiyet rolleri ile evlilik dışı cinsel yakınlığa yönelik tutum arasındaki ilişkiyi, cinsiyet değişkeni dışında tüm bağımsız değişkenlere göre ayrı ayrı analiz etmek için Tek Yönlü Manova Analizi kullanılmıştır. Toplumsal cinsiyet rolleri tutumunun ve evlilik dış1 cinsel yakınlı̆̆a yönelik tutumun cinsiyet değişkenine göre farklılık gösterip göstermediğini belirlemek amacı ile T testi yapılmıştır. 
YILDIRAY, Burcu ve Seher BALCI ÇELİK (2020). “Üniversite Öğrencilerinin Toplumsal Cinsiyet Rolleri ile Evlilik Dışı Cinsel Yakınlığa Yönelik Tutumları”, Mavi Atlas, 8(2): 196-209

\section{Bulgular}

\section{Toplumsal Cinsiyet Rolleri ile Evlilik Dışı Cinsel Yakınlığa Yönelik Tutum Arasındaki İlişki}

Üniversite öğrencilerinin toplumsal cinsiyet rolleri düzeyi ile evlilik dışı cinsel yakınlığa yönelik tutum düzeyleri arasında anlamlı bir ilişkinin olup olmadığını saptamak amacıyla Pearson Korelasyon Analizi yapılmış ve toplumsal cinsiyet rolleri ile evlilik dışı cinsel yakınlığa yönelik tutum arasında pozitif ve düşük düzeyde anlamlı bir ilişki bulunmuştur ( $r=.219 ; \mathrm{p}<.001)$.

\section{Toplumsal Cinsiyet Rolleri ile Evlilik Dışı Cinsel Yakınlığa Yönelik Tutum Arasındaki İlişkinin Cinsiyete Göre Farklılaşması}

Üniversite öğrencilerinin toplumsal cinsiyet rolleri düzeyinin cinsiyete göre anlamlı bir farklılık gösterip göstermediği Bağımsız Örneklem T- Testi ile test edilmiştir. Bulgular ise Tablo 1 'de verilmiştir.

Tablo 1: Üniversite Öğrencilerinin Cinsiyetlerine Göre Toplumsal Cinsiyet Rolleri Düzeyine İlişkin T-Testi Sonuçları

\begin{tabular}{|c|c|c|c|c|c|c|}
\hline & Cinsiyet & $\mathbf{N}$ & $\bar{x}$ & Ss & $\mathbf{t}$ & $\mathbf{P}$ \\
\hline & Kadın & 247 & 164.6559 & 17.82979 & & \\
\hline $\begin{array}{c}\text { Toplumsal } \\
\text { Cinsiyet Rolleri }\end{array}$ & Erkek & 174 & 153.6782 & 21.63197 & -5.691 & $.000^{*}$ \\
\hline
\end{tabular}

Tablo 1'e bakıldığında üniversite öğrencilerinin toplumsal cinsiyet rolleri düzeyinin cinsiyete göre anlamlı bir farklılık gösterdiği görülmektedir. $(\mathrm{t}=-5,691 ; \mathrm{p}<.001)$. Üniversite öğrencilerinin toplumsal cinsiyet rolleri düzeyine ilişkin puan ortalamalarına bakıldığında kadın $(\bar{x}=164,6559)$ erkek $(\bar{x}=153,6782)$ olarak bulunmuş olup kadınların puan ortalamalarının erkeklerin puan ortalamalarına göre daha yüksek olduğu saptanmıştır.

Tablo 2: Üniversite Öğrencilerinin Cinsiyetlerine Göre Evlilik Dışı Cinsel Yakınlığa Yönelik Tutum Düzeylerine İlişskin t-Testi Sonuçları

\begin{tabular}{|c|c|c|c|c|c|c|}
\hline & Cinsiyet & $\mathbf{N}$ & $\bar{x}$ & Ss & $\mathbf{t}$ & $\mathbf{P}$ \\
\hline Evlilik D1ş1 Cinsel & Kadın & 247 & 70.8745 & 20.75223 & & \\
\hline Yakınlığa Yönelik & & & & & 4.075 & $.000^{*}$ \\
\hline Tutum & Erkek & 174 & 78.9483 & 18.92861 & & \\
\hline
\end{tabular}

Tablo 2'ye bakıldığında üniversite öğrencilerinin evlilik dışı cinsel yakınlığa yönelik tutumlanı düzeyi cinsiyete göre anlamlı bir farklılık gösterdiği görülmektedir ( $\mathrm{t}=4,075 ; \mathrm{p}<.001)$. Tabloya bakıldığında erkeklerin puan ortalamasının $(\bar{x}=78,9483)$ kadınların puan ortalamasından $(\bar{x}=$ 70,8745) daha yüksek olduğu görülmektedir. 
YILDIRAY, Burcu ve Seher BALCI ÇELİK (2020). “Üniversite Öğrencilerinin Toplumsal Cinsiyet Rolleri ile Evlilik Dışı Cinsel Yakınlığa Yönelik Tutumları”, Mavi Atlas, 8(2): 196-209

\section{Toplumsal Cinsiyet Rolleri ile Evlilik Dışı Cinsel Yakınlığa Yönelik Tutum Arasındaki İlişkinin Öğrenim Görülen Fakülte Türüne Göre Farklılaşması}

Üniversite öğrencilerinin toplumsal cinsiyet rolleri ile evlilik dışı cinsel yakınlığa yönelik tutumları arasındaki ilişkinin öğrenim görülen fakülte türüne göre farklılaşıp farklılaşmadığını tespit etmek amacıyla Tek Yönlü Manova Analizi yapılmış ve sonuçları Tablo 3’te verilmiştir.

Tablo 3: Üniversite Öğrencilerinin Öğrenim Görülen Fakülte Türü Değişkenine İlişkin Tek Yönlü Manova Analizi

\begin{tabular}{|c|c|c|c|c|c|}
\hline \multirow{3}{*}{ Etki } & \multirow{3}{*}{ Wilk's Lambda } & \multirow{3}{*}{$\mathbf{F}$} & Hipotez & Hata & \multirow{3}{*}{$\mathbf{P}$} \\
\hline & & & Serbestlik & Serbestlik & \\
\hline & & & Derecesi & Derecesi & \\
\hline $\begin{array}{c}\text { Öğrenim Görülen } \\
\text { Fakülte }\end{array}$ & .878 & 3.450 & 16 & 822 & .000 \\
\hline
\end{tabular}

Tablo 3'e bakıldığında analiz sonucunda elde edilen değerler (Wilk's Lambda $(\Lambda)=.878$; $\left.\mathrm{F}_{16,822}=3,450 ; \mathrm{p}=.000\right)$ üniversite öğrencilerinin öğrenim görülen fakülte değisskenine göre toplumsal cinsiyet rolleri ve evlilik dışı cinsel yakınlığa yönelik tutumları arasında anlamlı bir farklılı̆̆ın olduğunu göstermektedir. Bu farklılıkların hangi gruplardan kaynaklandığını belirlemek amacıyla Tukey Testi yapılmış ve sonuçları Tablo 4 ve Tablo 5 'te verilmiştir.

Tablo 4: Üniversite Öğrencilerinin Öğrenim Görülen Fakülte Türüne Göre Toplumsal Cinsiyet Rollerine İlişkin Tukey Testi Sonuçları

\begin{tabular}{|c|c|c|c|c|}
\hline Gruplar & & Ortalama Farkı & $\begin{array}{c}\text { Standart } \\
\text { Hata }\end{array}$ & $\mathbf{P}$ \\
\hline \multirow[t]{4}{*}{ Ĕgitim Fakültesi } & Fen Edebiyat Fakültesi & $-10.7345^{*}$ & 3.31026 & .034 \\
\hline & Sağlık Bilimleri Fakültesi & $-13.0432^{*}$ & 4.17334 & .049 \\
\hline & Tip Fakültesi & & & \\
\hline & & $-13.4384^{*}$ & 3.94983 & .021 \\
\hline İlahiyat Fakültesi & Tıp Fakültesi & $-12.9824 *$ & 4.09388 & .043 \\
\hline \multirow[t]{4}{*}{ Ziraat Fakültesi } & Fen Edebiyat Fakültesi & $15.7246^{*}$ & 4.60373 & .022 \\
\hline & Sağlık Bilimleri Fakültesi & $-18.0333^{*}$ & 5.28782 & .020 \\
\hline & Tıp Fakültesi & & & \\
\hline & & $-18.4286^{*}$ & 5.11326 & .011 \\
\hline
\end{tabular}

$\overline{\mathrm{p}}<.05$

Tablo 4'e bakıldığında Eğitim Fakültesinde öğrenim gören öğrencilerin puan ortalamaları; Fen Edebiyat Fakültesi, Sağlık Bilimleri Fakültesi ve Tıp Fakültesinde öğrenim görmekte olan öğrencilerin puanlarından anlamlı olarak farklılık gösterdiği görülmektedir. Eğitim Fakültesinde okuyan öğrencilerin puan ortalamaları ( $\bar{x}=155,7901)$, Fen Edebiyat Fakültesinde $(\bar{x}=166,5246)$, Sağlık Bilimleri Fakültesinde $(\bar{x}=168,8333)$ ve Tip Fakültesinde $(\bar{x}=169,2286)$ okuyan öğrencilerin puan ortalamalarından daha düşük olduğu görülmektedir.

Tablo 5: Üniversite Öğrencilerinin Öğrenim Görülen Fakülte Türüne Göre Evlilik Dışı Cinsel Yakınlı̆̆a Yönelik Tutumlarına İlişkin Tukey Testi Sonuçları
Gruplar
Ortalama Fark1
Standart Hata
P 
YILDIRAY, Burcu ve Seher BALCI ÇELİK (2020). “Üniversite Öğrencilerinin Toplumsal Cinsiyet Rolleri ile Evlilik Dışı Cinsel Yakınlığa Yönelik Tutumları”, Mavi Atlas, 8(2): 196-209

\begin{tabular}{lllll}
\hline İlahiyat Fakültesi & Tip Fakültesi & $-13.1780^{*}$ & 4.20913 & .048 \\
& İ̈BF & $-14.4511^{*}$ & 4.24917 & .021
\end{tabular}

$\mathrm{p}<.05$

Tablo 5’e bakıldığında İlahiyat Fakültesi öğrencilerinin puanları Tıp Fakültesinde ve İktisadi ve İdari Bilimler Fakültesinde okuyan öğrencilerin puanlarından anlamlı bir şekilde farklılaştığ1 görülmektedir. İlahiyat Fakültesinde okuyan öğrencilerin puan ortalamaları $(\bar{x}=67,1107)$, Tip Fakültesinde okuyan öğrencilerin puan ortalamalarından $(\bar{x}=80,2857)$ ve İktisadi ve İdari Bilimler Fakültesinde okuyan öğrencilerin puan ortalamalarından $(\bar{x}=81,5588)$ daha düşüktür.

\section{Toplumsal Cinsiyet Rolleri ile Evlilik Dışı Cinsel Yakınlığa Yönelik Tutum Arasındaki İlişkinin Bireyin Yaşamının Büyük Bir Bölümünü Geçirdiği Yere Göre Farklılaşması}

Üniversite öğrencilerinin toplumsal cinsiyet rolleri ile evlilik dışı cinsel yakınlığa yönelik tutumları arasındaki ilişkinin bireyin yaşamının büyük bir bölümünü geçirdiği göre farklılaşıp farklılaşmadığını tespit etmek amacıyla Tek Yönlü Manova Analizi yapılmış ve sonuçları Tablo 6’da verilmiştir.

Tablo 6: Üniversite Öğrencilerinin Yaşanılan Yer Değisşkenine İlişsin Tek Yönlü Manova Analiz Sonuçları

\begin{tabular}{cccccc}
\hline \multirow{2}{*}{ Etki } & Wilk's Lambda & F & Hipotez & Hata \\
& & & Serbestlik & Serbestlik & P \\
& & & Derecesi & Derecesi & \\
\hline Yaşanılan Yer & .954 & 4.961 & 4 & 828 & .001 \\
\hline
\end{tabular}

Tablo 6'ya bakıldığında analiz sonucunda elde edilen değerler (Wilk's Lambda $(\Lambda)=.954$; $\left.\mathrm{F}_{4,828}=4,961 ; \mathrm{p}=.001\right)$ üniversite öğrencilerinin yaşanılan yer değişkenine göre toplumsal cinsiyet rolleri ve evlilik dışı cinsel yakınlığa yönelik tutum arasında anlamlı bir farklılı̆̆ın olduğunu göstermektedir. Bu farklılıkların hangi gruplardan kaynaklandığını belirlemek amacıyla Tukey Testi yapılmış ve sonuçları Tablo 7 ve Tablo 8'de verilmiştir.

Tablo 7: Üniversite Öğrencilerinin Yaşanılan Yere Göre Toplumsal Cinsiyet Rollerine İlişkin Tukey Testi Sonuçları

\begin{tabular}{llccc}
\hline \multicolumn{1}{c}{ Gruplar } & & Ortalama Farki & Standart Hata & P \\
\hline Köy & İlçe & $-9.7963^{*}$ & 3.30419 & .009 \\
& Şehir & $-12.0622^{*}$ & 2.96880 & .000 \\
\multirow{2}{*}{ İlçe } & Köy & $9.7963^{*}$ & 3.30419 & .009 \\
& Şehir & -2.2659 & 2.27476 & .580 \\
\multirow{2}{*}{ Şehir } & Köy & $12.0622^{*}$ & 2.96880 & .000 \\
& İlçe & 2.2659 & 2.27476 & .580
\end{tabular}

$\alpha=.05 / 2=.025$

Tablo 7'ye bakıldığında köyde yaşayan bireylerin toplumsal cinsiyet rolleri ile ilçede yaşayan ve şehirde yaşayan bireylerin toplumsal cinsiyet rolleri arasında anlamlı bir fark olduğu görülmektedir. Köyde yaşayan bireylerin puan ortalamaları $(\bar{x}=150,3519)$, ilçede $(\bar{x}=160,1481)$ ve şehirde $(\bar{x}=162,4141)$ yaşayan bireylerin puan ortalamalarından daha düşüktür. 
YILDIRAY, Burcu ve Seher BALCI ÇELİK (2020). "Üniversite Öğrencilerinin Toplumsal Cinsiyet Rolleri ile Evlilik Dışı Cinsel Yakınlığa Yönelik Tutumları”, Mavi Atlas, 8(2): 196-209

Tablo 8: Üniversite Öğrencilerinin Yaşanılan Yere Göre Evlilik Dışı Cinsel Yakınlı̆̆a Yönelik Tutumlarına İlişkin Tukey Testi Sonuçları

\begin{tabular}{llccc}
\hline \multicolumn{1}{c}{ Gruplar } & & Ortalama Farki & Standart Hata & P \\
\hline Köy & İlçe & -5.2222 & 3.34688 & .264 \\
& Şehir & $-8.4032^{*}$ & 3.00715 & .015 \\
\multirow{2}{*}{ İlçe } & Köy & 5.2222 & 3.34688 & .264 \\
& Şehir & -2.2659 & 2.30415 & .352 \\
\multirow{2}{*}{ Şehir } & Köy & $12.0622^{*}$ & 3.00715 & .015 \\
& İlçe & 2.2659 & 2.30415 & .352
\end{tabular}

$\alpha=.05 / 2=.025$

Tablo 8’e bakıldığında köyde yaşayan bireylerin evlilik dışı cinsel yakınlığa yönelik tutumları ile şehirde yaşayan bireylerin evlilik dışı cinsel yakınlığa yönelik tutumları arasında anlamlı bir fark olduğu görülmektedir. Köyde yaşayan bireylerin puan ortalamaları $(\bar{x}=67,9444)$ şehirde $(\bar{x}=76,3477)$ yaşayan bireylerin puan ortalamalarından daha düşüktür.

Toplumsal Cinsiyet Rolleri ile Evlilik Dışı Cinsel Yakınlığa Yönelik Tutum Arasındaki İlişkinin Bireyin Sosyo-Ekonomik Durumuna Göre Farklılaşması

Üniversite öğrencilerinin toplumsal cinsiyet rolleri ile evlilik dışı cinsel yakınlığa yönelik tutumları arasındaki ilişkinin bireyin sosyo-ekonomik durumuna göre farklılaşıp farklılaşmadığını tespit etmek amacıyla Tek Yönlü Manova Analizi yapılmış ve sonuçları Tablo 9'da verilmiştir.

Tablo 9: Üniversite Öğrencilerinin Sosyoekonomik Durum Değişkenine Göre Tek Yönlü Manova Analizi Sonuçları

\begin{tabular}{|c|c|c|c|c|c|}
\hline & & & Hipotez & Hata & \\
\hline Etki & Wilk's Lambda & $\mathbf{F}$ & $\begin{array}{c}\text { Serbestlik } \\
\text { Derecesi }\end{array}$ & $\begin{array}{c}\text { Serbestlik } \\
\text { Derecesi }\end{array}$ & $\mathbf{P}$ \\
\hline $\begin{array}{c}\text { Sosyoekonomik } \\
\text { Durum }\end{array}$ & .989 & 1.108 & 4 & 828 & .352 \\
\hline
\end{tabular}

Tablo 9'a bakıldığında analiz sonucunda elde edilen değerler (Wilk's Lambda $(\Lambda)=.989$; $\left.\mathrm{F}_{4,828}=4,961 ; \mathrm{p}=.352\right)$ üniversite öğrencilerinin yaşanılan yer değişkenine göre toplumsal cinsiyet rolleri ve evlilik dışı cinsel yakınlığa yönelik tutum arasında anlamlı bir farklılığın olmadığını göstermektedir.

\section{Tartışma}

$\mathrm{Bu}$ araştırmanın amacı kapsamında etik kuruldan gerekli izin alındıktan sonra (Ondokuz Mayıs Üniversitesi Sosyal ve Beşeri Bilimler Etik Kurulu, 17.04.2020 tarihli ve 2020/160 no’lu karar) veriler toplanılmaya başlanmış ve elde edilen verilerden yapılan analizler sonucunda toplumsal cinsiyet rolleri ile evlilik dişı cinsel yakınlığa yönelik tutum arasında pozitif yönde düşük düzeyde bir ilişki bulunmuştur. Bu sonuca göre bireylerin cinsel yakınlı̆̆1 yaşamalarında sahip oldukları toplumsal cinsiyet rolleri az da olsa etkilidir. Bu etkinin az olmasının nedeni cinselliğin sadece sahip olunan toplumsal cinsiyet rolü gibi kişisel unsurlardan etkilenmemesi, din, kültür ve gelenekler gibi diş unsurlandan da etkilenmesi olabilir. Ülkemizde toplumsal cinsiyet rolleri ile evlilik dışı cinsel yakınlığa yönelik tutum arasındaki ilişkiyi inceleyen bir araştırma bulunmamaktadır. Bununla beraber toplumsal cinsiyet rolleri ile cinselliğe ilişkin kavramlar arasındaki ilişkinin araştırıldığı çalışmalar bulunmaktadır. Örneğin Döner (2015), yaptığı araştırmada toplumsal cinsiyet rolleri ile cinsel mitler arasındaki ilişkiyi incelemiş ve aralarında anlamlı bir ilişki bulmuştur. 
Kıylığlu (2015), yaptığı araştırmada toplumsal cinsiyet rollerinin riskli cinsel davranış ve cinsel yolla bulaşan hastalıklar üzerinde etkili olduğunu, güvenli ya da güvenli olmayan bir şekilde cinsel ilişkiye girmenin genellikle erkeklerin kararıyla şekillendiğini belirtmiştir. Aksoy Derya ve ark. (2017), toplumsal cinsiyet rolleri ve cinsel tabu arasındaki ilişkiyi incelemiş ve sonuç olarak homoseksüelliği tabu olarak gören öğrencilerin daha eşitlikçi tutuma sahip olduğu ve kadına yönelik cinsel tabuları kabul eden öğrencilerin daha eşitlikçi bir tutuma sahip olduğunu bulmuşlardır. Yurt dışındaki araştırmalara bakıldığında ise Greig ve ark. (2008), toplumsal cinsiyet rollerini HIV ve AIDS gibi hastalıkların kaynağı ile ilişkilendirmiş, erkeklerin sahip olduğu rollerden dolayı, daha fazla cinsel ilişkiye girme ve daha riskli cinsel ilişkiye girme davranışı gösterdiklerini belirtmişlerdir.

Toplumsal cinsiyet rolleri ile evlilik dişı cinsel yakınlı̆̆a yönelik tutum arasındaki ilişkinin cinsiyete göre farklılaşıp farklılaşmadığını tespit etmek amacıyla yapılan analizlerde anlamlı bir farklılık saptanmıştır. Katılımcıların toplumsal cinsiyet rolleri düzeyine bakıldığında kadınların puan ortalamalarının $(\bar{x}=164,6559)$ erkeklerin puan ortalamalarından $(\bar{x}=153,6782)$ daha yüksek olduğu görülmektedir. Araştırmanın bulgularından yola çıkılarak kadınların ve erkeklerin eşitlikçi bir tutuma sahip olduğu fakat kadınların erkeklerden daha fazla eşitlikçi bir tutuma sahip olduğu söylenebilir. Bu durumun sebebi kadınların kadın-erkek eşitliğini erkeklerden daha fazla savunmalarından kaynaklanıyor olabilir. Arıcı (2011), Başar (2012), Seçgin ve Tural (2011) ve Yaşar (2011), araştırmalarında cinsiyete göre toplumsal cinsiyet rollerinde bir farklılaşma olup olmadığını test etmişler ve aralarında anlamlı bir ilişki bulmuşlardır. İncelenen araştırma bulguları, yapılan bu araştırmanın bulguları ile örtüşmektedir. Yurt dışında yapılan araştırmalara bakıldığında ise Tu ve Liao (2005) ile Al-Ghanim ve Badabah (2016) yaptıkları araştırmalarda toplumsal cinsiyet rollerinin cinsiyete göre anlamlı bir farklılık gösterdiğini tespit etmişlerdir ve sonuçlar bu araştırmanın bulguları ile örtüşmektedir. Katılımcıların evlilik dışı cinsel yakınlığa yönelik tutumlarına bakıldığında ise erkeklerin puan ortalamalarının $(\bar{x}=78,9483)$ kadınların puan ortalamalarından $(\bar{x}=70,8745)$ daha yüksek olduğu görülmektedir. Bu durumda erkek öğrencilerinin kadın öğrencilere oranla evlilik dışı cinsel yakınlığa yönelik daha olumlu bir tutuma sahip olduğu söylenebilir. Diğer bir ifade ile çalışma grubundaki erkek öğrenciler, kadın erkeklere oranla evlilik dışında cinsel yakınlık kurmaya daha 1 lımlı bakmaktadırlar. Bu durumun sebebi, yaşanılan toplumun kadınları cinsellik konusunda erkeklere oranla daha fazla baskılaması olabilir. Yıldıray ve ark. (2019), yaptıklar1 araştırmada cinsiyete ile evlilik dışı cinsel yakınlığa yönelik tutum arasında anlamlı bir ilişki bulmuşlardır ve sonuçlar bu araştırmanın bulguları ile örtüşmektedir. Yapılan benzer araştırmalara bakıldığında ise Adak (2016), üniversite öğrencileri ile yaptığı araştırmada erkeklerin partneri ile evlenmeden birlikte yaşamaya daha olumlu yaklaştıklarını tespit etmiştir. Bu bulgu, yapılan araştırma sonuçları ile örtüşmektedir. Yurt dışında yapılan araştırmalara bakıldığında ise Blair ve Scott (2019), yaptığı araştırmada erkeklerin ilişkilerinde fiziksel olarak kadınlardan daha fazla yakınlık kurduklarını ve cinsel yakınlığı başlatmada erkeklerin kadınlardan daha 1lımlı yaklaştıklarını tespit etmişlerdir. Sonuçlar bu araştırmanın bulguları ile benzerlik göstermektedir. Ayrıca Buunk (1980), evlilik dışı cinsel ilişki olgusunu incelemiş ve cinsiyetler arasında anlamlı bir ilişki bulmuştur. Sonuçlar ise bu araştırmanın sonuçları ile benzerlik göstermektedir.

Toplumsal cinsiyet rolleri ile evlilik dışı cinsel yakınlığa yönelik tutum arasındaki ilişkinin öğrenim görülen fakülte türüne göre farklılaşıp farklılaşmadığını tespit etmek amacıyla yapılan analizlerde ise anlamlı bir farklılık saptanmıştır. Katılımcıların toplumsal cinsiyet rollerine bakıldığında Eğitim Fakültesinde öğrenim görmekte olan bireylerin puan ortalamalarının $(\bar{x}=155,7901)$ Fen Edebiyat Fakültesinde $(\bar{x}=166,5246)$, Sağlık Bilimleri Fakültesinde $(\bar{x}=168,8333)$ ve Tip Fakültesinde $(\bar{x}=169,2286)$ ögrenim görmekte olan öğrencilerin puan ortalamalarından anlamlı bir şekilde farklılaştığı, Eğitim Fakültesinde okuyan öğrencilerin bahsi geçen diğer fakültelere oranla daha düşük ortalamalara sahip olduğu görülmektedir. Araştırmanın bulgularından yola çıkılarak, Eğitim Fakültesinde öğrenim görmekte olan öğrencilerin diğer fakültelere oranla 
kadın-erkek eşitliğini daha az savunduğu söylenebilir. Yaşar (2011) ve Başçı (2016), yaptıkları araştırmalarda öğrenim görülen fakülte türü ile toplumsal cinsiyet rolleri arasında anlamlı bir ilişki bulmuş olup incelenen araştırma bulguları yapılan araştırma bulguları ile örtüşmektedir. Katılımcıların evlilik dışı cinsel yakınlığa yönelik tutumlarına bakıldığında ise İlahiyat Fakültesinde öğrenim görmekte olan öğrenciler ile Tip Fakültesi ve İktisadi ve İdari Bilimler Fakültesinde öğrenim görmekte olan öğrenciler arasında anlamlı farklılaşmanın olduğu görülmektedir. İlahiyat Fakültesinde okuyan öğrencilerinin puan ortalaması $(\bar{x}=67,1077)$ Tip Fakültesinde okuyan öğrencilerin $(\overline{\mathrm{x}}=80,2857)$ ve İktisadi ve İdari Bilimler Fakültesinde okuyan öğrencilerin $(\overline{\mathrm{x}}=81$, 5588) puan ortalamalarından daha düşüktür. İlahiyat Fakültesinde öğrenim görmekte olan öğrenciler, Tıp Fakültesi ve İktisadi ve İdari Bilimler Fakültesinde öğrenim görmekte olan öğrencilere oranla evlilik dışı cinsel yakınlığa daha olumsuz yaklaşmaktadırlar. Öğrenim görülen fakülte türüne göre öğrencilerin ölçekten aldıkları puan ortalamalarına bakıldığında İlahiyat Fakültesinde öğrenim görmekte olan bireylerin, grupta bulunan diğer bütün öğrencilere oranla evlilik dışı cinsel yakınlık kurmaya daha olumsuz baktıkları görülmektedir. Bu durumun sebebi, öğrencilerin aldıkları eğitimin içeriğinden kaynaklanıyor olabilir. Yıldıray ve ark. (2019), yaptıkları araştırmada öğrenim görülen fakülte türüne ile evlilik dışı cinsel yakınlığa yönelik tutum arasında anlamlı bir ilişki bulmuş ve sonuçlar bu araştırmanın sonuçları ile örtüşmektedir.

Toplumsal cinsiyet rolleri ile evlilik dışı cinsel yakınlığa yönelik tutum arasındaki ilişkinin bireyin yaşamının büyük bir bölümünü geçirdiği yere göre farklılaşıp farklılaşmadığını tespit etmek amacıyla yapılan analizlerde anlamlı bir farklılık saptanmıştır. Katılımcıların toplumsal cinsiyet rollerine bakıldığında köyde yaşayan bireylerin puan ortalamaları ile ilçede yaşayan ve şehirde yaşayan bireylerin puan ortalamaları arasında anlamlı bir farklılaşma görülmektedir. Köyde yaşayan bireylerin puan ortalamaları $(\overline{\mathrm{x}}=150,3519)$, ilçede $(\overline{\mathrm{x}}=159,9541)$ ve şehirde $(\overline{\mathrm{x}}=162,2326)$ yaşayan bireylerin puan ortalamalarından daha düşüktür. Köyde yaşayan bireylerin diğerlerine oranla daha az eşitlikçi tutuma sahip olduğu söylenebilir. Bunların yanı sıra "köyde", "ilç̧ede", ve "şehirde" yaşayan bireylerin puan ortalamaları onların eşitlikçi tutuma sahip olabileceğini göstermektedir. $\mathrm{Bu}$ durum, bireylerin yaşadıkları çevrenin toplumsal cinsiyet rollerine ilişkin bakış açılarından kaynaklanıyor olabilir. Bireylerin yaşadıkları yer, onların kadın-erkek eşitliğine olan bakış açılarını etkilemiş olabilir. Başçı (2016) ve Karakaş (2018) araştırmalarında yaşanılan yer ile toplumsal cinsiyet rolleri arasında anlamlı bir ilişki bulmuştur. İncelenen araştırmalar bu araştırmanın bulguları ile örtüşmektedir. Bunun yanı sıra Arıcı (2011) ve Yaşar (2011) ise yaptıkları araştırmalarında ise yaşanılan yer ile toplumsal cinsiyet rolleri arasında anlamlı bir ilişki bulmamışır ve bu araştırmalar bu araştırmanın bulguları ile çelişmektedir. Bu durumun sebebi örneklem farklılığından veya araştırmaya dahil edilen kişi sayısından kaynaklanmış olabilir. Yurt dışında yapılan araştırmalara bakıldığında ise Trommsdorf ve Iwawaki (1989) ile Tu ve Liao (2005), yaptıkları araştırmalarda toplumsal cinsiyet rollerini yaşanılan ülke bazında incelemişler ve ülkeler arasında anlamlı bir farklılık bulmuşlardır. Sonuçlar, bu araştırmanın bulguları ile benzerlik göstermektedir. Katılımcıların evlilik dışı cinsel yakınlığa yönelik tutumlarına bakıldığında köyde yaşayan ve şehirde yaşayan bireyler arasında anlamlı bir farklılık görülürken ilçede yaşayan bireyler arasında anlamlı bir fark görülmemiştir. Köyde yaşayan bireylerin puan ortalaması $(\bar{x}=67,9444)$ şehirde yaşayan bireylerin puan ortalamasından ( $\bar{x}=75,9961)$ daha düşüktür ve sonuçlara bakıldığında köyde yaşayan bireylerin diğer yerleşim yerlerinde yaşayan bireylere oranla daha az olumlu tutuma sahip olduğu görülmektedir. Çalışma grubundaki şehirde yaşayan bireyler, köyde yaşayan bireylere oranla evlilik dışında cinsel yakınlık kurmaya daha ılımlı yaklaşmaktadırlar. Bu durumun sebebi, bireylerin yaşadıkları yerin cinselliği yaşamaya olanak verip vermemesi olabilir. Örneğin, köy gibi küçük bir yerde yaşayan birey, şehir gibi büyük bir yerde yaşan bireye oranla cinselliğini yaşarken daha çekingen davranabilir. 
Toplumsal cinsiyet rolleri ile evlilik dışı cinsel yakınlı̆ga yönelik tutum arasındaki ilişkinin bireyin sosyo-ekonomik durumuna göre farklılaşıp farklılaşmadığını tespit etmek amacıyla yapılan analizlerde ise anlamlı bir farkın olmadığı görülmüştür. Bu durumun sebebi, örneklem hatasından ya da örneklem sayısının azlığından kaynaklanıyor olabilir. Değişkenler ayrı ayrı incelendiğinde Gökçay (2018) ve Çınar (2018), kendi araştırmalarında toplumsal cinsiyet rollerini gelir düzeylerine göre incelemiş ve aralarında anlamlı bir farklılık bulmamışlardır. Bu durum, bu araştırma sonuçları ile örtüşmektedir. Bunun yanı sıra Karakaş (2018) ve Kamışlı (2018) ise kendi araştırmalarında gelir düzeyi ile toplumsal cinsiyet rolleri arasında anlamlı bir farklılık bulmuşlardır ve sonuçları bu araştırma sonuçları ile çelişmektedir. Bu durumun sebebi örneklem farkl1lı̆̆ından veya araştırmaya dahil edilen kişi sayısından kaynaklanmış olabilir. Yurt dışında yapılan araştırmalara bakıldığında ise Tu ve Liao (2005), gelir düzeyine göre toplumsal cinsiyet rolleri arasinda anlamlı bir fark bulmuşlardır ve bu sonuç yapılan bu araştırmanın bulguları ile çelişmektedir.

\section{Öneriler}

Bu araştırma, Ondokuz Mayıs Üniversitesi'nde lisans öğrenimi görmekte olan 421 öğrenci ile yapılmıştır. Bu araştırmaya ön lisans düzeyi ve lisansüstü düzeyinde olan öğrenciler de katılabilir, farklı üniversitelerde öğrenim görmekte olan öğrenciler de araştırma kapsamına dahil edilebilir. Bunların yanı sıra araştırma kapsamında incelenen cinsiyet, öğrenim görülen fakülte, sosyoekonomik durum, bireyin yaşamının büyük bölümünü geçirdiği yer, anne ve baba eğitim düzeyleri değişkenlerine yaş, sınıf düzeyi, romantik ilişki durumu gibi değişkenler de eklenebilir. Ayrıca bu araştırma sonuçları, üniversite öğrencilerinin eşitlikçi bir tutuma sahip olduğunu göstermekle beraber, özellikle ülkemizde toplumsal cinsiyet rollerine ilişkin hala ayrımcllı̆ın olduğunu göstermektedir. Özellikle çocukların ebeveynleri dışında en çok vakit geçirdiği ortam olan okullarda cinsiyet eşitliğine yönelik etkinlikler yapılabilir. Bilhassa öğretmenlerin cinsiyet ayrımcılı̆̆ına yönelik tutumlarını dikkatle irdeleyip çocuklara cinsiyetçi tutumlarını yansıtmamalıdır. Öğrencilerin ders kitapları, cinsiyetçi tutumu yansıtan ifadeler veya görseller bulundurup bulundurmadığını tespit etmek amaciyla uzmanlar tarafından tekrardan incelenebilir. Bunların yanında cinsellik olgusunun ülkemizde hala konuşulması çekinilen bir olgu olduğu bilinmektedir. Bu durumda çocukların cinsellik, cinsel yakınlık gibi kavramları hakkında bilgilendirilmeli ve bilhassa ilköğretim ve ortaöğretim seviyesi öğrencileri için ders müfredatlarına gelişim süreçlerine uygun olmak üzere cinsellik ve cinsel sağlık ile ilgili dersler eklenebilir.

\section{Kaynakça}

ADAK, Nurşen (2016). "Evlilik veya Evlilik Dış1 Birlikte Yaşama: Üniversite Öğrencileri Üzerine Bir Araştırma”, Sosyoloji Dergisi(Armağan Sayısi), 23-40. Yayınevi.

ADLER, Alfred (2019). Cinsiyetler Arasinda İsbirlĭgi, çev. Seçkin Selvi, İstanbul: Payel

AKIN, Ayşe ve Simge DEMİREL (2003). “Toplumsal Cinsiyet Kavramı ve Sağlığa Etkileri”, Cumburiyet Üniversitesi Tip Fakültesi, 25(4): 73-82.

AKSOY DERYA, Yeşim; TİMUR TAŞHAN, Sermin; UÇAR, Tuba; KARAASLAN, Tuba ve Özgül AKBAŞ TUNÇ (2017). "Toplumsal Cinsiyete İlişkin Tutumların Cinsel Tabulara Etkisi”, Gümüşhane Üniversitesi Sağlk Bilimleri Dergisi, 6(1): 1-8.

AL-GHANIM, Kaltham A. \& Abdallah M. BADAHDAH (2017). "Gender Roles in the Arab World: Development and Psychometric Properties of the Arab Adolescents Gender Roles Attitude Scale", Sex Roles, 77: 169-177 
YILDIRAY, Burcu ve Seher BALCI ÇELİK (2020). "Üniversite Öğrencilerinin Toplumsal Cinsiyet Rolleri ile Evlilik Dışı Cinsel Yakınlığa Yönelik Tutumları”, Mavi Atlas, 8(2): 196-209

ARICI, Fatma (2011). Üniversite Öğrencilerinde Toplumsal Cinsiyet Rollerine İlişkin Algılar ve Psikolojik İyi Oluş, (Yayımlanmamış Yüksek Lisans Tezi), Hacettepe Üniversitesi, Sosyal Bilimler Enstitüsü, Ankara.

BAKIRCIOĞLU, Rasim (2011). Çocuk ve Ergende Ruh Sağhl̆ğ, Ankara: An1 Yayıncilık.

BAŞAR, Fatma (2012). Türkiye'deki Hemşirelik Öğrencilerinin Toplumsal Cinsiyet Rollerine İlişkin Tutumları, (Yayımlanmamış Doktora Tezi), Marmara Üniversitesi, Sağlık Bilimleri Enstitüsü, İstanbul.

BAŞÇI, Bilge (2016). Öğrencilerin Toplumsal Cinsiyet Rollerine İlişkin Tutumlarının Çok Değişkenli İstatistiksel Tekniklerle Analizi, (Yayımlanmamış Yüksek Lisans Tezi), Marmara Üniversitesi, Sosyal Bilimler Enstitüsü, İstanbul.

BLAİR, Sampson Lee \& Christina L. SCOT'T (2019). "It Started with a Kiss: The Initiation of Sexual Intimacy Among Young Adults in China", Sexuality and Culture, 23: 1147-1166.

BOZDEMIR, Nafiz ve Sevgi ÖZCAN (2011). "Cinselliğe ve Cinsel Sağlığa Genel Bakış", Turkish Journal of Family Medicine and Primary Care, 5(4): 37-46.

BUUNK, Bram (1980). "Extramarital Sex in the Netherlands Motivations in Social and Marital Context", Alternative Lifestyles, 3(1): 11-39.

Cinsel Eğitim ve Tedavi Araștırma Derneği (2007). Cinsel Yașam ve Sorunlar, İstanbul: Cinsel Eğitim ve Tedavi Araştırma Derneği Yayınları.

ÇINAR, Gizem (2018). Cumhuriyet Üniversitesi Edebiyat Fakültesi Öğrencilerinin Toplumsal Cinsiyet Rollerine Göre Şiddet Eğilimi Üzerine Olan Sosyal Algılarının Araştırılması, (Yayımlanmamış Yüksek Lisans Tezi), Cumhuriyet Üniversitesi, Sosyal Bilimler Enstitüsü, Sivas.

DÖNER, Aslı Çağla (2015). Cinsel Mitlerin, Evlilik Doyumu ve Toplumsal Cinsiyet Rolleri Arasındaki İlişkinin İncelenmesi, (Yayımlanmamış Yüksek Lisans Tezi), Üsküdar Üniversitesi, Sosyal Bilimler Enstitüsü, İstanbul.

ECEVIT, Yıldız (2011). “Toplumsal Cinsiyet Sosyolojisine Başlangıç”, Toplumsal Cinsiyet Sosyolojisi, ed. Y. Ecevit, ve N. Karkıner, ss 2-31, Eskişehir: Anadolu Üniversitesi Yayınları.

ERTÜRK, Elvan Melek (2017). “Toplumsal Cinsiyet”, Davranıs Bilimleri, ed. Mehmet Zencirkıran, ss. 377-408, Bursa: Dora Yayıncilik. Kitaplığ1.

FREUD, Sigmund (2017). Cinsellik Üzerine Üç Deneme, çev. Beyza Nur Doğan, Ankara: Gece

GÖKÇAY, Gönül (2018). Kadınların Toplumsal Cinsiyet Rollerine İlişkin Tutumlarının Belirlenmesi, (Yayımlanmamış Yüksek Lisans Tezi), Kafkas Üniversitesi, Sağlık Bilimleri Enstitüsü, Kars.

GREİG, Alan; PEACOCK, Dean; JEWKES, Rachel \& Sisonke MSIMANG (2008). "Gender and AIDS: Time To Act", National Instituties of Healts, 22(2): 35-43.

HAYTA, M. Kemal ve Osman ALGIN (2013). Assk ve Flört Kıskacında Ergen. İstanbul: Timaş Yayınları.

KAMIŞLI, Ecem (2018). Toplumsal Cinsiyet Rolleri ve Aile İşlevselliğinin Problem Çözme Becerilerine Etkisi, (Yayımlanmamış Yüksek Lisans Tezi), İstanbul Ticaret Üniversitesi, Sosyal Bilimler Enstitüsü, İstanbul. 
YILDIRAY, Burcu ve Seher BALCI ÇELİK (2020). "Üniversite Öğrencilerinin Toplumsal Cinsiyet Rolleri ile Evlilik Dışı Cinsel Yakınlığa Yönelik Tutumları”, Mavi Atlas, 8(2): 196-209

KARAKAŞ, Didar (2018). Evli Kadınların Toplumsal Cinsiyet Rollerine İlişkin Tutumlarının Evlilik Uyumuna Etkisi, (Yayımlanmamış Yüksek Lisans Tezi), Ondokuz Mayıs Üniversitesi, Sağlık Bilimleri Enstitüsü, Samsun.

KIYLIOĞLU, Levent (2015). “Toplumsal Cinsiyet Rolleri ve Kadının HIV Riski”, Sosyal Hizmet Sempozyumu Özet Kitabı, ed. F. Şahin, ss 433-437, Manisa: Celal Bayar Üniversitesi, Sağlik Yüksekokulu, Sosyal Hizmet Bölümü.

SABUNCUOĞLU, Ayda (2006). Televizyon Reklamlarında Toplumsal Cinsiyet, (Yayımlanmamış Yüksek Lisans Tezi), Ege Üniversitesi, Sosyal Bilimler Enstitüsü, İzmir.

SEÇGIN, Fadime ve Ayşegül TURAL (2011). "Sınıf Öğretmenliği Bölümü Öğretmen Adaylarının Toplumsal Cinsiyet Rollerine İlisskin Tutumları", e-Journal of New World Sciences Academy Education Science, 6(4): 2446-2458.

TARHAN, Nevzat (2010). Kadm Psikolojisi, İstanbul: Nesil Yayınları.

TAŞÇI, Ali İhsan (2017). Cinsiyet Ë̆gitimi. İstanbul: Hayat Sağlık ve Sosyal Hizmetler Vakfi.

TROMMSDORFF, Gisela \& Saburo IWAWAKI (1989). "Students' Perceptions of Socialisation and Gender Role in Japan and Germany", International Journal of Behavioral Development, 12(4): 485-493.

TU, Su-Hao \& Pei-Shan LİAO (2005). "Gender Differences in Gender-Role Attitudes: A Comparative Analysis of Taiwan and Coastal China", Journal of Comparative Family Studies, 36(4), 545-566.

YAŞAR, Bakiye (2011). Öğretmen Adaylarının Toplumsal Cinsiyet Rolleri Tutumlarının Kadın Sağlığı Hemşireliği Açısından Değerlendirilmesi, (Yayımlanmamış Yüksek Lisans Tezi), Mersin Üniversitesi, Sağlık Bilimleri Enstitüsü, Mersin.

YEŞİLTEPE OSKAY, Ümran (2005). "Kadınlarda Orgazmın Kültürel ve Psikososyal Boyutu”, Androloji Bülteni, 22: 261-263.

YILDIRAY, Burcu; KILIÇ Aslı; AYDIN, Arife; AKDEMIR, Emre; ve Nihat SAĞLAM (2019). "Evlilik Dışı Cinsel Yakınlığa Yönelik Tutum Ölçeği: Geçerlik ve Güvenirlik Çalışması", Uluslararsı Multidisipliner Sosyal Bilimler Kongresi Tam Metinler Kitabı, ed. S. Çeçen, ve Z. Karacagil, ss. 45-56, Ankara: Bilgin Kültür Sanat Yayınları.

ZEYNELOĞLU, Simge (2008). Ankara'da Hemşirelik Öğrenimi Gören Üniversite Öğrencilerinin Toplumsal Cinsiyet Rollerine İlişkin Tutumları, (Yayımlanmamış Doktora Tezi), Hacettepe Üniversitesi, Sağlık Bilimleri Enstitüsü, Ankara.

ZEYNELOĞLU, Simge ve Füsun TERŻ̇ĞLU (2011). “Toplumsal Cinsiyet Rolleri Tutum Ölçeğinin Geliştirilmesi ve Psikometrik Özellikleri” Hacettepe Üniversitesi Eğitim Fakültesi Dergisi, (40): 409-420.

World Health Organization (2002). Defining Sexual Health, Geneva: World Health Organization. 
YILDIRAY, Burcu ve Seher BALCI ÇELİK (2020). “Üniversite Öğrencilerinin Toplumsal Cinsiyet Rolleri ile Evlilik Dışı Cinsel Yakınlığa Yönelik Tutumları”, Mavi Atlas, 8(2): 196-209

Ek

\section{Etik Kurul Onayı Belgesi}

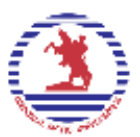

ONDOKUZ MAYIS ÜNIVERSITESI

SOSYAL VE BEŞERI BILIMLER ETIK KURUL KARARLARI

\begin{tabular}{|c|c|c|}
\hline KARAR TARIHII & TOPLANTI SAYISI & KARAR SAYISI \\
\hline 17.04 .2020 & 3 & $2020 / 160$ \\
\hline
\end{tabular}

KARAR NO: Üniversitemiz Eğitim Bilimleri Enstitüsū Yüksek Lisans ōğrencisi Burcu 2020/160 YILDIRAY' in Prof. Dr. Seher BALCI ÇELİ danışmanlığında "Üniversite Ögrencilerinin Toplumsal Cinsiyet Rolleri İe Evlilik Dıșı Cinsel Yakınlığa Yönelik Tutumlan Arasındaki llișki" isimli seminer çalışmasım içeren 9848 sayll dilekçesi okunarak görüşüldï.

Üniversitemiz Eğitim Bilimleri Enstitüsū Yüksek Lisans öğrencisi Burcu YILDIRAY" in Prof. Dr. Seher BALCI ÇELIK danışmanlığında "Üniversite Öğrencilerinin Toplumsal Cinsiyet Rolleri İle Evlilik Dışı Cinsel Yakınlığa Yönelik Tutumlan Arasındaki liş̧ki” isimli seminer çalışmasının kabulüne oy birliği ile karar verildi. 